\title{
Physical activity level measured by doubly labeled water and accelerometry in children
}

Citation for published version (APA):

Hoos, M. B., Plasqui, G., Gerver, W. J. M., \& Westerterp, K. R. (2003). Physical activity level measured by doubly labeled water and accelerometry in children. European Journal of Applied Physiology and Occupational Physiology, 89(6), 624-626. https://doi.org/10.1007/s00421-003-0891-6

Document status and date:

Published: 01/01/2003

DOI:

10.1007/s00421-003-0891-6

Document Version:

Publisher's PDF, also known as Version of record

Document license:

Taverne

Please check the document version of this publication:

- A submitted manuscript is the version of the article upon submission and before peer-review. There can be important differences between the submitted version and the official published version of record.

People interested in the research are advised to contact the author for the final version of the publication, or visit the DOI to the publisher's website.

- The final author version and the galley proof are versions of the publication after peer review.

- The final published version features the final layout of the paper including the volume, issue and page numbers.

Link to publication

\footnotetext{
General rights rights.

- You may freely distribute the URL identifying the publication in the public portal. please follow below link for the End User Agreement:

www.umlib.nl/taverne-license

Take down policy

If you believe that this document breaches copyright please contact us at:

repository@maastrichtuniversity.nl

providing details and we will investigate your claim.
}

Copyright and moral rights for the publications made accessible in the public portal are retained by the authors and/or other copyright owners and it is a condition of accessing publications that users recognise and abide by the legal requirements associated with these

- Users may download and print one copy of any publication from the public portal for the purpose of private study or research.

- You may not further distribute the material or use it for any profit-making activity or commercial gain

If the publication is distributed under the terms of Article $25 \mathrm{fa}$ of the Dutch Copyright Act, indicated by the "Taverne" license above, 


\section{Physical activity level measured by doubly labeled water and accelerometry in children}

\begin{abstract}
The present study investigated the use of a triaxial accelerometer, Tracmor2, for the measurement of physical activity in children. Eleven children [age 6.9 (2.2) years, body mass 19.5 (5.3) $\mathrm{kg}$ and height 112.3 $(14.4) \mathrm{cm}$ ] were studied. Total daily energy expenditure (TDEE) was measured using the doubly labeled water method over a 2-week period. In addition, basal metabolic rate (BMR) was determined by the ventilated hood system. Physical activity level (PAL) was defined as TDEE/BMR. Tracmor2 was worn during the same 2-week period throughout waking hours after which average counts per day were calculated. The average counts per day were shown to be highly correlated to PAL values measured by doubly labeled water: $\mathrm{PAL}=1.156 \times 10^{-5} \times$ Tracmor 2 average counts day ${ }^{-1}$ $+0.978(r=0.79, P<0.01)$. In conclusion, Tracmor2 is a valid instrument to measure physical activity in children under free-living conditions.
\end{abstract}

Keywords Total daily energy expenditure ·

Accelerometer - Tracmor - Physical activity level ·

Doubly labeled water

\section{Introduction}

Physical activity and physical fitness are important for health and development. Inactivity increases the risk of diseases associated with our modern lifestyle. Because physical inactivity in childhood has been found to continue into adulthood, the promotion of regular physical

M. B. Hoos $(\square) \cdot$ W.-J. M. Gerver

Department of Pediatrics, University of Maastricht,

PO Box 5800, 6202 AZ Maastricht, The Netherlands

E-mail: marije.hoos@kg.unimaas.nl

Tel.: + 31-433-874297

Fax: + 31-433-875246

G. Plasqui · K. R. Westerterp

Department of Human Biology, University of Maastricht, PO Box 616, 6200 MD Maastricht, The Netherlands activity in children could serve as a preventive health strategy. Bringing about changes in habitual lifestyles requires an understanding of the current levels and patterns of physical activity.

The doubly labeled water (DLW) method is regarded as the 'gold standard' for the measurement of physical activity. It estimates physical activity under free-living conditions over a period of 1-2 weeks. However labeled water is expensive, not always available and cannot be used for the measurement of physical activity patterns. Accelerometers, validated against DLW, are a good alternative for the measurement of physical activity patterns.

Accelerometers register the occurrence and intensity of body movement. Two classes of accelerometers are described in the literature: uni-axial and tri-axial accelerometers. Johnson et al. (1998) validated the Caltrac device, which measures accelerations in one direction. Compared with the DLW method the Caltrac was found to be inaccurate. Ekelund et al. (2000) used a Computer Science and Applications (CSA) activity monitor, which is also a uni-axial accelerometer, and found a good correlation between the accelerometer and DLW data. In contrast, Leenders et al. showed an underestimation of physical activity expressed as kilocalories per day measured by the CSA (Leenders et al. 2001) and the Tritrac, a tri-axial accelerometer. Another tri-axial accelerometer, the Tracmor did prove to be a reliable tool for assessing physical activity in adults (Bouten et al. 1996).

The present study validates the Tracmor2 in children. The Tracmor 2 is, in contrast to the Tracmor used by Bouten et al. (1996), a much smaller and lighter device, which minimizes subject discomfort.

\section{Methods}

Subjects and study design

Eleven children in the age range of 3-12 years were selected. The children were healthy and free from any medical condition that 
could restrict their physical activity. The children visited the hospital early in the morning for basal metabolic rate (BMR) measurements. From that moment, the Tracmor2 was worn for a period of 2 weeks. The evening preceding the BMR measurement the children received a dose of ${ }^{2} \mathrm{H}_{2}{ }^{18} \mathrm{O}$. During the 2-week period, urine samples were collected and stored at $-20^{\circ} \mathrm{C}$ until ${ }^{2} \mathrm{H}$ and ${ }^{18} \mathrm{O}$ enrichments were measured. Parents and children were informed about the study before informed consent was obtained. The study was approved by the Ethical Committee of the University Hospital Maastricht.

\section{DLW and ventilated hood}

Estimating physical activity by DLW requires information about total daily energy expenditure (TDEE) and BMR. TDEE was measured by the DLW method according to the Maastricht protocol (Westerterp et al. 1995). A weighed dose of water with a measured enrichment of about 5 at $\%{ }^{2} \mathrm{H}$ and 10 at $\%{ }^{18} \mathrm{O}$ was ingested during the evening preceding the BMR measurement. This dose results in an initial excess body water enrichment of $150 \mathrm{ppm}$ for ${ }^{2} \mathrm{H}$ and $300 \mathrm{ppm}$ for ${ }^{18} \mathrm{O}$. A baseline urine sample was collected before dosing. Additional urine samples were collected in the mornings and evenings of days 1, 8 and 15. Samples were analyzed on an isotope-ratio mass spectrometer (Optima; VG Isogas, Middlewich, Cheshire, UK).

The hydrogen isotope is eliminated from the body as water, while the oxygen isotope is eliminated as both water and carbon dioxide. The difference between the two elimination rates is therefore a measure of carbon dioxide production. Total daily energy expenditure was calculated, using Weir's equations (Weir 1949), from carbon dioxide production assuming a respiratory quotient of 0.85 .

BMR was measured using an open-circuit, ventilated hood system in the morning after an overnight fast. The subjects were asked to lie in supine position for $30 \mathrm{~min}$. Gas analyses were made with a paramagnetic oxygen analyzer (Servomex type 500A, Crowborough, Sussex, UK) and with an infrared carbon dioxide analyzer (Servomex type 500A), similar to the system described by Schoffelen et al. (1997). Oxygen consumption and carbon dioxide production were calculated using the flow through the hood and the oxygen and carbon dioxide concentrations in the incoming and outgoing air. Weir's equations were used to calculate BMR (Weir 1949). Knowing TDEE and BMR, physical activity level (PAL) can be calculated as: TDEE/BMR.

\section{Accelerometer}

The Tracmor2 (Tracmor2, Philips Research, Eindhoven, The Netherlands), a tri-axial accelerometer, was worn for 2 weeks. The Tracmor2 is a small $(7 \times 2.8 \times 0.8 \mathrm{~cm})$ and light $(30 \mathrm{~g})$ device, which is worn attached to an elastic belt at the back of the waist. The tri-axial accelerometer calculates the sum of the rectified and integrated acceleration curves from the anteroposterior, mediolateral and vertical directions of the trunk. The integration period was set at $1 \mathrm{~min}$ and the final output is expressed as counts per minute (cpm) (Bouten et al. 1996).

The Tracmor2 was worn during waking hours, except while showering and during swimming. The parents of the children recorded the moments when the children woke up, put the Tracmor2 on and off and went to bed. If the time during which they wore the device and the time spent sleeping did not add up to at least $22 \mathrm{~h}$, the day was excluded from the analysis (mean number of recorded days 11). Average daily counts were calculated.

\section{Statistics}

A linear regression analysis was performed for the PAL (TDEE/ BMR) measured with the DLW method and the Tracmor2 (average counts per day) output.

\section{Results}

Subject characteristics are given in Table 1. The mean age (SD) of the children was 6.9 (2.2) years, body mass was $19.5(5.3) \mathrm{kg}$ and height was $112.3(14.4) \mathrm{cm}$. Linear regression analysis resulted in the following equation for the calculation of PAL values (Fig. 1): $\mathrm{PAL}=$ $1.156 \times 10^{-5} \times$ Tracmor2 average counts day ${ }^{-1}+0.978$ $(r=0.79, P<0.01)$.

\section{Discussion}

As our awareness of the effect of inactivity on health, growth and development increases, so does the interest in methods to measure physical activity. Because physical inactivity in children continues into adulthood, prevention of inactivity is especially in this age group of great importance. When measuring physical activity, one has to be sure that the measurement does not interfere with the child's lifestyle. Accelerometers are therefore a good alternative for the DLW method, which is considered to be the 'gold standard'.

The present study showed the Tracmor 2 to be a valuable instrument for the evaluation of physical activity in children. Bouten et al. (1996) compared activity counts from the Tracmor with energy expenditure in

Table 1 Subject characteristics. TDEE Total daily energy expenditure; BMR basal metabolic rate

\begin{tabular}{|c|c|c|c|c|c|c|c|}
\hline Subject no. & Age (years) & $\operatorname{Sex}(M / F)$ & Height $(\mathrm{cm})$ & Mass $(\mathrm{kg})$ & k Counts day ${ }^{-1}$ & TDEE (MJ) & $\mathrm{BMR}(\mathrm{MJ})$ \\
\hline 1 & 5.9 & $\mathrm{~F}$ & 100.3 & 18.0 & 30.7 & 5.06 & 3.69 \\
\hline 2 & 6.8 & $\mathrm{~F}$ & 103.8 & 15.0 & 34.3 & 5.45 & 4.40 \\
\hline 4 & 11.1 & M & 130.9 & 25.2 & 60.8 & 8.29 & 4.54 \\
\hline 5 & 6.6 & $\mathrm{~F}$ & 103.7 & 14.8 & 34.1 & 4.64 & 3.43 \\
\hline 6 & 3.4 & $\mathrm{~F}$ & 97.4 & 15.4 & 39.2 & 5.26 & 3.56 \\
\hline 9 & 4.9 & M & 101.7 & 16.7 & 48.3 & 6.25 & 4.00 \\
\hline 10 & 9.8 & M & 128.8 & 23.5 & 53.4 & 7.27 & 4.47 \\
\hline 11 & 7.1 & $\mathrm{~F}$ & 128.6 & 26.4 & 58.7 & 7.57 & 4.64 \\
\hline
\end{tabular}




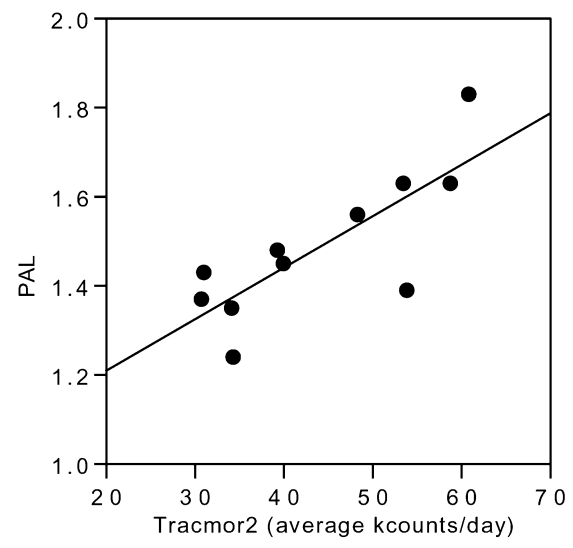

Fig. 1 Physical activity levels (PAL $=$ total daily energy expenditure/basal metabolic rate) measured by the doubly labeled water technique plotted against the average daily Tracmor 2 counts. The solid line represents the regression line: PAL $=1.156 \times 10^{-5} \times$ Tracmor2 average counts day ${ }^{-1}+0.978(r=0.79 . P<0.01)$

adult subjects. A correlation coefficient of 0.58 $(P<0.001)$ was found. The correlation improved to a value comparable with those of the present study (0.73) when counts were corrected for counts that were the results of vibrations produced by transportation. Because these vibrations are removed by a low-pass filter in Tracmor2, this correction is not necessary when using the device.

Two other studies in children describe the validation of an accelerometer. Johnson et al. (1998) did not find a relation between Caltrac and DLW data. Ekelund et al. (2000) found a correlation of 0.54 between average activity counts and physical activity measured by DLW using the CSA. Another study in women did not find a relation between CSA and DLW data (Leenders et al. 2001). Like Johnson et al. (1998) this study converted accelerometer output to kilocalories per day on the basis of an equation including age, height, mass and gender.

In addition to the CSA, the study showed the Trictrac, a tri-axial accelerometer, to underestimate physical activity. Also Tritrac output was converted to kcalories per day with use of equations based on mass, height, sex and age. This means that the measurement of physical activity depends in addition to accelerometer output on subject characteristics.

The lower correlation found by Ekelund et al. (2000) compared with the present study can probably be contributed to the fact that Ekelund used the CSA accelerometer, which is a uni-axial accelerometer. This device only registers movements in the vertical plane in contrast to the Tracmor, which measures movements in three directions.

The position of attachment to the body can also influence accelerometer output. Ideally several accelerometers are used attached to different sites to the body; however this is very unpleasant for the subject. Therefore the Tracmor, CSA and Tritrac are attached to the waist, which is close to the center of gravity. The Caltrac was not attached to the waist, but to the hip.

When measuring physical activity it is important not to disturb the regular pattern of physical activity. Therefore it is important to minimize the subject's discomfort. The Tracmor2 is worn around the waist attached to an elastic belt. Because the Tracmor2 is a small device it can be covered invisible with clothing. In addition the Tracmor2 is a light device compared with other accelerometers.

We conclude that because the Tracmor 2 can be used under free-living conditions, does not interfere with the child's habitual activity pattern and it was shown to be highly correlated to the DLW method, it is a valuable device for the assessment of physical activity in children.

\section{References}

Bouten CV, Verboeket-van de Venne WP, Westerterp KR, Verduin M, Janssen JD (1996) Daily physical activity assessment: comparison between movement registration and doubly labeled water. J Appl Physiol 81 2:1019-1026

Ekelund E, Sjostrom M, Yngve A, Poortvliet E, Nilsson A, Froberg K, Wedderkopp N, Westerterp K (2000) Physical activity assessed by activity monitor and doubly labeled water in children. Med Sci Sports Exerc 33 2:275-281

Johnson RK, Russ J, Goran MI (1998) Physical activity related energy expenditure in children by doubly labeled water as compared with the Caltrac accelerometer. Int J Obes 22:10461052

Leenders NY, Sherman WM, Nagaraja HN, Kien CL (2001) Evaluation of methods to assess physical activity in free-living conditions. Med Sci Sports Exerc 33 7:1233-1240

Schoffelen PFM, Westerterp KR, Saris WHM, Ten Hoor F (1997) A dual-respiration chamber system with automated calibration. J Appl Physiol 83:2064-2072

Weir JB (1949) New methods for calculating metabolic rate with special reference to protein metabolism. J Physiol (Lond) 109: $1-9$

Westerterp KR, Wouters L, Van Marken-Lichtenbelt W (1995) The Maastricht protocol for the measurement of body composition and energy expenditure with labeled water. Obes Res 3 [Suppl 1]:49-57 